\title{
Effects of Financial Market Variables on Stock Prices on the Example of the Market Rates of the Listed Companies: A Review of the Literature
}

\author{
Mihaela Cristina Onica ${ }^{\star}$
}

\begin{tabular}{l}
\hline \multicolumn{1}{c}{ A R T I C L E I N F O } \\
\hline Article history: \\
Accepted December 2020 \\
Available online December 2020 \\
\hline JEL Classification \\
G32, G33, G39 \\
Keywords: \\
Stock exchange rates, Market \\
capitalization, PER market \\
capitalization coefficient, Price-to- \\
sell-ratio indexes, Stock indicators \\
\hline
\end{tabular}

\begin{abstract}
A B S T R A C T
In the actual context of the economic globalization, the financing on the financial market has become a modern alternative for the financing from the monetary market, so that the main users of financial information will be the investors. The real growth of the activity of one company is best reflected by using the stock growth rates, as they reflect the best argument regarding the fact that the management at the level of the entity was efficient and credible for the future investors on the capital market. Through efficient management decisions, the activity within the entity was carried out through commercial profitability and return conditions and these aspects are seen as appropriate by the market, increasing its credibility in the respective entity.
\end{abstract}

(c) 2020 EAI. All rights reserved.

\section{Introduction}

The stock exchange rates or the capital investments' return rates are the most extensive measurements of the performances of one company, as they reflect the conjunct influence of the financial risk and return rates. These stock indicators are calculated using the current exchange rate, and in order to express the other elements that are part of the calculus, we can use previous, current or foreseen values. The calculus method of these indicators depends on the existing financial-accounting data, on the analysts' previsions as well as on the investors' needs.

\section{Market capitalization and the market capitalization coefficient}

Market capitalization represents one of the basis indicators that feature a capital market. It shows the market value of all companies that are active on the stock exchange. Market capitalization reflects the market value of the company, and it considers all the objective and subjective components that reflect the activity of the company.

Market capitalization (MK) is calculated as the product between the current price of a share (PPA) and the total number of shares (NA) issued by the company, according to the relation:

$$
\mathrm{CB}=\mathrm{PPA} \times \mathrm{NA}
$$

Regarding the analysis of the market capitalization, we can appreciate that: market capitalization represents the market value of a company which is listed on the stock exchange and it reflects the public opinion regarding the net value of the company, as it is a decisive factor for the evaluation of the actions. It does not always reflect the real value of the company, as it is the case of the merging or acquisition offers, when the evaluation of the company is made considering more factors that provide value to the business. A large and increasing value of market capitalization is an objective pursued by each investor on the capital market. Market capitalization is one of the best indicators of liquidity, showing the ease through which the titles of the respective company can be traded, especially from the perspective of an investor which has placed large amounts of money in shares and who desires to know to which extent he/she is being given the possibility of finding a counterpart in case he/she wants to sell the respective shares. This features becomes very important for the selection of the titles in the structure of one portfolio depending on theipr market capitalization. From this point of view, companies are classified in three large categories: large capitalization (large caps), medium capitalization (midcaps) and respectively reduced capitalization (small caps). 
Market capitalization is also the first indicator which we consider when talking about the size of a stock exchange, representing the sum of the market value (market capitalization) of all companies listed on an organized market. As a result, market capitalization is one of the basic indicators that feature a capital market.

The market capitalization coefficient (P/E or PER - from the English "price-to-earnings ratio")shows to which extent investors are willing to pay for a monetary unit of a reported profit.

Market capitalization coefficient is one of the most publicized indicators for a public interest company. The indicator is important due to the fact that, combined with the foreseen earnings of the company, it provides analysts with the possibility of deciding whether the shares are over or under evaluated. (EPS).

It is calculated as the ratio between the market price of a share (PPA) and the earning per share

$$
\mathrm{PER}=\frac{\mathrm{PPA}}{\mathrm{EPS}} \text { unde, } \mathrm{Eps}=\frac{\mathrm{P} \text { net }}{\mathrm{Na}}
$$

PER estimates in how many years the made investment is recovered, assuming that the whole profit is distributed to the stakeholders as equities (it is relevant to cash equities). The PER shows how much the investor must invest in order to obtain a monetary unit from the company's earnings. Thus, a relatively high PER defines an expensive and probably over valuated share and a relatively low PER defines a cheap and good for acquisition share.

Regarding the analysis of the market capitalization coefficient, we appreciate that its relevance to the stock market analysis has certain limitations:

- In a static approach, it is normal that a low PER share to be preferred to a high PER one. But the owner of the share owns the rights over future revenues to the same extent at the current ones, and the current profit brought by its transferable security can be very different to its future profits. In this conditions, it is possible that a higher PER share to be more profitable that the one with a lower PER if there is the perspective of rapidly growing profits and implicitly equities in the following exercises. Therefore, the PER analysis would also consider the growth or the reduction of the incomes corresponding to the share in the future.

- There are situations where a higher value of the indicator can be explained through the expectation of a higher increase rate or through the reduction of the risk. As investors are interested by the future performances of one company, the historical PER loses its significance, as the PER based on forecasts of future profits becomes much more interesting.

Table 1 Market capitalization and the market capitalization coefficient on the financial entity, between 2017 and 2019

\begin{tabular}{|c|c|c|c|c|}
\hline Symbol & Formula & 2017 & 2018 & 2019 \\
\hline \multirow{2}{*}{$\mathrm{CB}$} & $\mathrm{CB}=\mathrm{PPA} \times \mathrm{NA}$ & $\mathrm{CB}=2,5 \times 892_{\nu} 296$ & $\mathrm{CB}=2,5 \times 976134$ & $\mathrm{CB}=2,5 \times 976134$ \\
\cline { 3 - 5 } & & $\mathrm{CB}=2230740$ & $\mathrm{CB}=2440335$ & $\mathrm{CB}=2440335$ \\
\hline \multirow{2}{*}{$\mathrm{PER}$} & $\mathrm{PER}=\frac{\mathrm{PPA}}{\mathrm{EPS}}$ & $\mathrm{PER}=\frac{2,5}{0,314}=7,959$ & $\mathrm{PER}=\frac{2,5}{0,074}=33,713$ & $\mathrm{PER}=\frac{2,5}{0,115}=21,619$ \\
\hline
\end{tabular}

Source: processed by the author

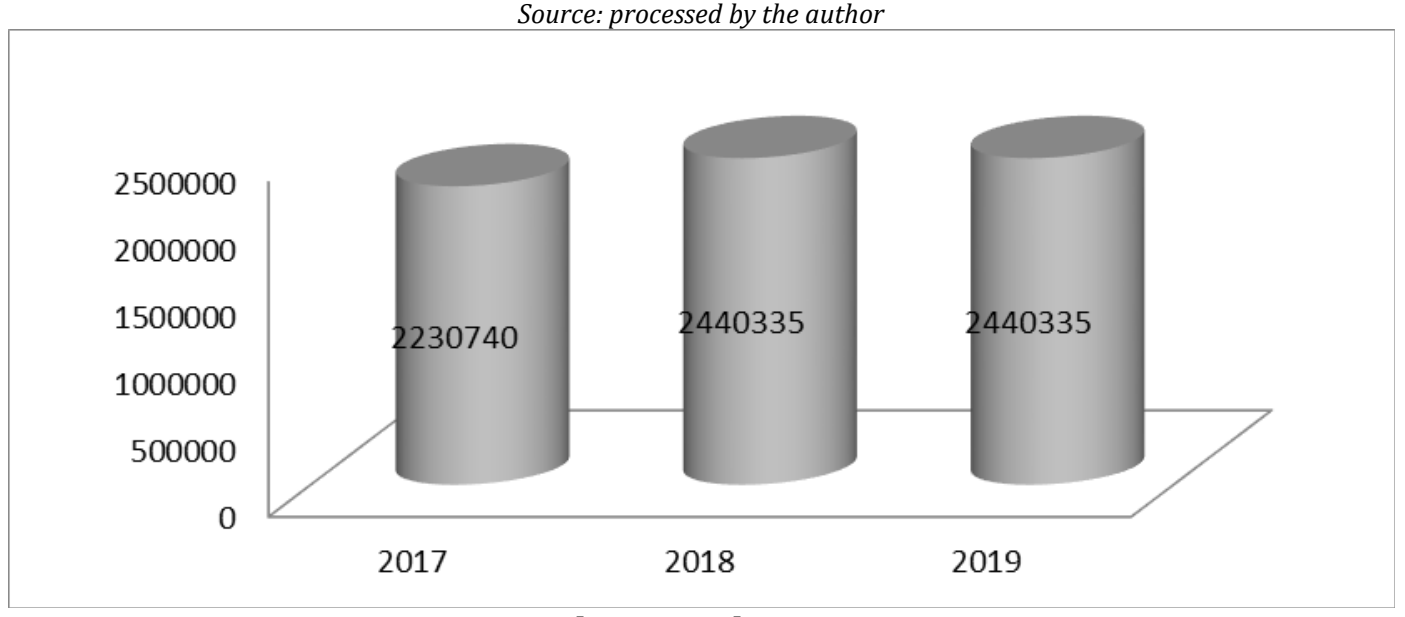

Figure 1. Market capitalization 2017-2019 
The PER market capitalization coefficient presents a 32\% growth in 2018 compared to 2017 and a decrease of $36 \%$ in 2019 compared to 2018. The growth of the market capitalization coefficient in 2018 compared to 2017 is the result of the decreasing profit per share, with $117 \%$ compared to the price per share that stagnated in the three studied years. The decrease of the market capitalization coefficient is due to the $55 \%$ increase of the profit per share.

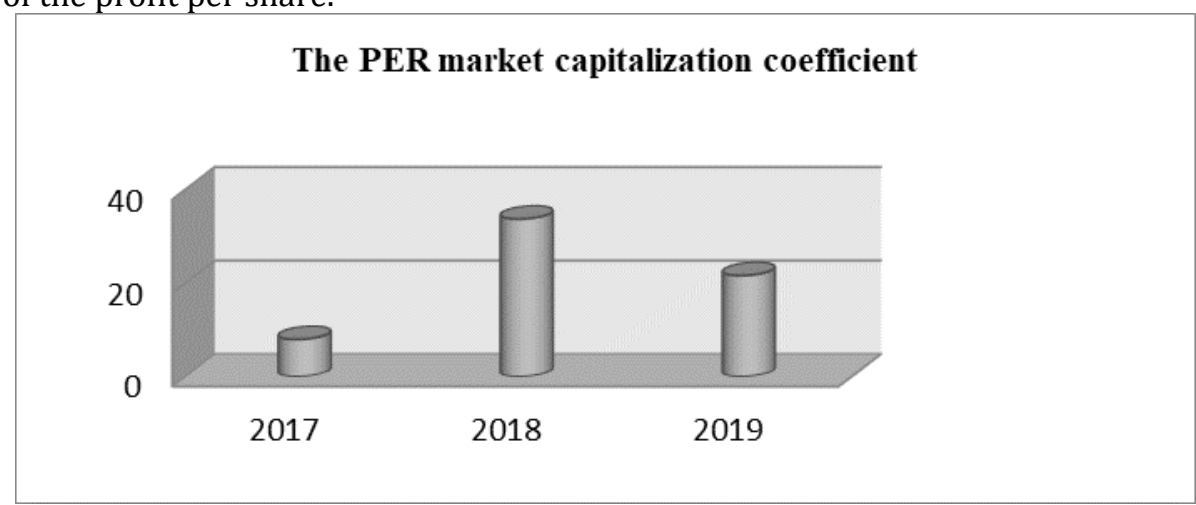

Figure 2. PER market capitalization coefficient 2017-2019

As we can also see in the above chart, it displays a slight decrease in 2019 , and, the lower its value, the better signaled status. It is one of the most used ratios on the market and it reflects the price investors are willing to pay for a unit of net profit per share.

\section{The earning per share}

The earning per share (EPS) shows how much net result a share produces during a financial exercise and is determined according to the relation:

$$
\mathrm{BPS}=\frac{\mathrm{RNE}}{\mathrm{NA}}, \text { where }
$$

$\mathrm{RNE}=$ the net result of the exercise

$\mathrm{NA}=$ total number of shares issued by the company.

The EPS indicator is designed to have a significant impact on the share price and therefore a significant role in the decision making process of the investors. EPS is a very relevant mean for the comparison of the entities' performance, as it is not affected by the equity sharing policy.

Table 2 presents the earning per share on the listed financial entity, between 2017 and 2019.

Table 2. Earning per share 2017-2019

\begin{tabular}{|c|c|c|c|c|}
\hline Symbol & Formula & 2017 & 2018 & 2019 \\
\hline EPS & EPS $=\frac{\text { RNE }}{\mathrm{NA}}$ & EPS $=\frac{280262}{892296}=0,314$ & EPS $=\frac{72386}{976134}=0,074$ & EPS $=\frac{121127}{976134}=0,124$ \\
\hline
\end{tabular}

Earnings per share EPS presents a 68\% increase in 2019 compared to 2018 and a $76 \%$ decrease in 2018 compared to 2017. The growth of the earning per share in 2019 compared to 2018 is due to the increase of the net result per exercise, a $76 \%$ increase, compared to the shares number which stagnated during the last two years. The decrease of the earning per share is due to the $76 \%$ decrease of the net earnings per share, with a more significant value than the growth of the shares number, namely $9 \%$.

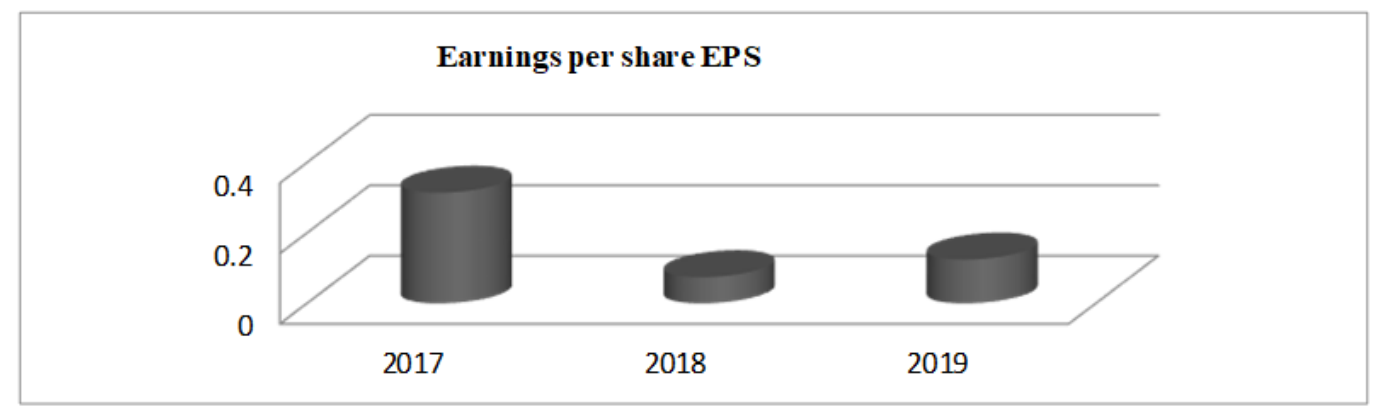

Figure 3. Earnings per share EPS between, 2017-2019 
This indicator has a special significance when the results of a company are compared on a certain period of time or when the results of one company are compared to the result of similar companies in the same industry.

\section{Price-to-book-ratio and Price-to-sales-ratio Indicators}

Price to book ratio (PBR) and Price to sales ratio (PSR) indexes are the most used for the identification of value accumulation for the share and for the identification of profitable and non-profitable investments. These indicators are used to compare companies.

\section{PBR or P/B - „Price-to-Book-Ratio"index}

Determined as the ratio between the market value of a share (PPA) and the accounting value of a share (AVS) represents another important ratio as it indicates the value the financial market give to the management of a company. The calculus relation is:

$$
\begin{gathered}
\mathrm{PBR}=\frac{\mathrm{PPA}}{\mathrm{VCA}} \text { where, } \mathrm{VCA}=\frac{\text { net mntaks }}{\text { shares no }} \\
\text { net intake }=\text { net assets }+ \text { evaluation differences(adjustments) }
\end{gathered}
$$

Regarding the analysis of the ratio between the market value and the price to book value of a share (PBR), one must consider the following issues: a well-managed entity with also sufficient growth possibilities should have a higher or at least equal market value to the accounting value of its share capital.

Generally speaking, companies with a higher profitability rate, compared to the equity and with a significant growth rhythm of the profit and of the turnover from a period to another, have reported a higher PBR (even more than 3), while companies with lower profitability rates and with a stability of the turnover reported a lower PBR.

From the perspective of analysts, the shares of a company with low PBR represent a "safe" investment, through the fact that the accounting value is a level that "supports" the market exchange. Accounting value is considered the level beneath which the market price would not fall, as the company would anytime have the option of liquidating or selling its shares for their accounting value. Though a low PBR is considered capable of insuring a "safety margin", many analysts avoid shares with high PBR when developing a portfolio. They start from the idea given the fact that the other indexes remain identical, for two shares, the one with lower PBR is safer.

If a company is listed on a lower price than its booking value (PBR has a sub-unitary value), it usually means that either the market considers the assets value as being over-valuated, either that the company has a very low profitability (or even negative profitability) of the assets. In the first case, it is recommended to sell the shares, as one can register a correction of the assets' value and thus the investor is exposed to the risk of reaching a negative profitability. If the second variant is true, there is the possibility that a change in the management staff of the company of new conditions of doing the business to determine a positive change in the profitability of the activity. A high value of the indicator can also represent a high profitability of the company's activity.

As a conclusion, the values of this ratio depend both on the general economic factors (or available for the respective field) and on factors that only consider that company as a distinctive entity.

A mean value of PBR at the level of developed economies in the industrial field reaches 1.7, representing a market value that exceeds by 1.7 times the booking value of a share. market.

This indicator can be an identification method of low price companies, which were neglected by the

PSR or P/S index - „Price-to Sales Ratio”meaning the ratio between the market price of a share (PPA) ant the net turnover (NT) that corresponds to a share or as a ratio between the market capitalization (MC) and the turnover of a company (TO), calculated according to the relation:

$$
\text { PSR }=\frac{\text { PPA }}{\text { NTO }} \text { Sau PSR }=\frac{\text { MC }}{\text { TO }}
$$

Regarding the analysis of the ratio between the market price of a share corresponding to a unit of turnover, we can appreciate the following:

- Practice has shown that this indicator is more useful for the identification of unprofitable investments, than in the discovery of profitable ones. Moreover, analysts that use it claim that it is especially useful when evaluating the shares of companies with low or unprofitable revenues, especially due to the fact that in their case, the PER calculus proves to be inoperative, without providing significant meanings.

- This index proves to be useful when other indexes cannot be used either because the company reports loses, either it has abnormal profitability or margins. Evaluation based on the turnover is relevant when 
we pursue the estimation of one company's value, which at a certain moment in time, has very low or even negative margins and which is expected to return to the normal activity or to be taken over.

- It is not recommended to compare the value of the index inter-fields, but it is indicated to make a comparison between the indexes of companies that have pretty similar activities.

Table 3 Price-to-book-ratio and Price-to-sell-ratio indexes, 2017-2019

\begin{tabular}{|l|c|c|c|c|}
\hline $\begin{array}{c}\text { Symbo } \\
l\end{array}$ & Formula & \multicolumn{1}{|c|}{2017} & 2018 & 2019 \\
\hline $\mathrm{PBR}$ & $\mathrm{PBR}=\frac{\mathrm{PPA}}{\mathrm{VCA}}$ & $\mathrm{PBR}=\frac{2,5}{7,256}=0,344$ & $\mathrm{PBR}=\frac{2,5}{7,229}=0,345$ & $\mathrm{PBR}=\frac{2,5}{7,076}=0,353$ \\
\hline $\mathrm{PSR}$ & $\mathrm{PSR}=\frac{\mathrm{CB}}{\mathrm{CA}}$ & $\mathrm{PSR}=\frac{2230740}{16976416}=0,131$ & $\mathrm{PSR}=\frac{2440335}{7341611}=0,332$ & $\mathrm{PSR}=\frac{2440335}{9305004}=0,262$ \\
\hline
\end{tabular}

Interpretation "Price-to-book-ratio and Price-to-sell-ratio indexes"

PBR index 2018 registers a 1\% increase compared to 2017, respectively, in 2019 it registers a 3\% increase reported to 2018. The growth of the price-to-book ratio in 2018 compared to 2017 is based on the decrease of the booking value of $1 \%$ per share and respectively on the maintenance of the share price during the last three years. The growth in 2019 compared to 2018 is also the result of the 3\% decrease in the booking value of a share.

The PSR index presents a 153\% growth in 2018 compared to 2017 and a 21\% decrease in 2019 compared to 2018. The growth of the price-to-sales-ratio indicator in 2018 reported to 2017 is based on the decrease of a turnover in a higher percentage, namely 57\%, compared to the market capitalization, which only grew by $9 \%$. The decrease of the price-to-book-ratio is generated by the $27 \%$ increase in the turnover, in a higher proportion than the market capitalization, which stagnated.

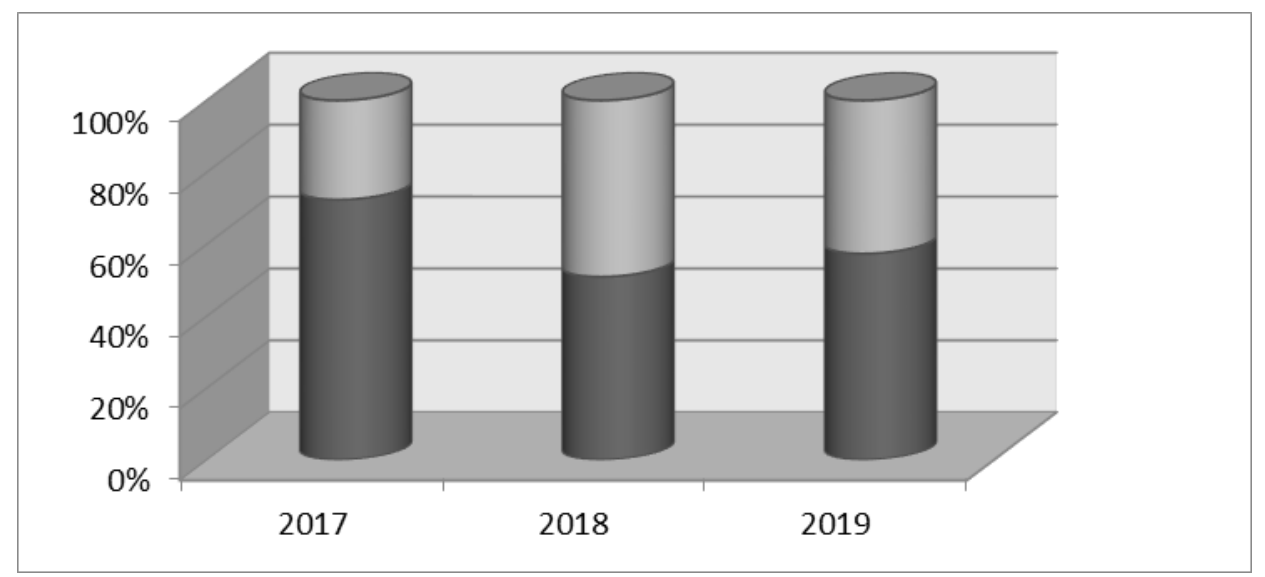

Figure 4. Price-to-book-ratio and Price-to-sales-ratio indexes, 2017-2019

The price to book ratio index represents a significant ration as it indicates the value financial markets give to the leading staff of a company, and the price to sale ratio index represents the ratio between the market price of a share and the net turnover.

\section{Dividend yield}

Dividend yield (DY) or the dividend capitalization ratio measures the profits of the stakeholders subsequently to the investments in the company's shares. It is determined as a ratio between dividend per share (DPS) and the market price of a share (MPS), according to the relation:

$$
\mathrm{DY}=\frac{\mathrm{DPS}}{\mathrm{MPS}} \times 100, \text { where DPS }=\frac{\mathrm{DIN}}{\mathrm{NA}}
$$

DIV $=$ the value of the dividends distributed to stakeholders in a financial exercise

$\mathrm{NA}=$ the number of common issued shares on the market

Dividend yield represents an evaluation of the stakeholders' revenues subsequently to the investment in the company's shares. If dividends are not given, this does not mean that the company has a descending trend (as profit increases), but this means that the company uses the profit for investments. 


\section{Conclusions}

Price to book ratio index is one of the most used indicators when evaluating the share price. The low value of this indicator shows the fact that the shares of the company are under-valuated by the market, also showing that investors have a weak trust in the perspective of the company. PRICE earnings ratio (PER) is the most frequently used evaluation multiple of listed companies. The reason is simple: the ultimate scope of each company is to gain profit, and its size provides the value of the company in the end. The analyzed company has lower values, meaning that for an investor, a lower PER is more convenient, as it represents a faster recovery through profit from the initially made investment. Due to the fact that the earnings per share reports a decrease, it results that the company cannot maintain the profit increase rhythm for years, which the investor is most interested about. As it has decreasing values, the index cannot encourage the investor to buy the share, which leads to the decrease in its price. Hence the company does not give dividends, we cannot calculate the dividend yield, which represents an evaluation of the profit gained by stakeholders, but if dividends are distributed, it means that the investment trend of the company is ascending, showing that the economic moment pursues long-time activity, aiming at reaching future profits for the stakeholders.

\section{References}

1. $\quad$ Anghel I., Evaluarea întreprinderii, Editura Economică, București, 2011;

2. Anghel I., Falimentul, radiografie și predicție, Editura Economică, București, 2002;

3. Armeanu S. D., Vintilă G., Moscalu M., Utilizarea tehnicilor de analiză cantitativă a datelor pentru estimarea riscului de faliment al corporațiilor, Economie teoretică și aplicată, Volumul XIX, No. 1(566), 2012;

4. Băileșteanu Gh., Diagnostic, risc și eficiență, Editura Mirton, Timișoara, Ediția a II-a, 1998;

5. Colasse, B., Analiza financiară a întreprinderii, traducere Tabără Neculai, Editura TIPOMOLDOVA, Iași, 2009.

6. Dinu E., Curea S.C.: Therelevance of the discriminant analysis in the evolution of the shares on the stock market. In: Theoretical and Applied Economics, 2009;

7. Ghic Gratiela, Analiza economico-financiară, Editura Universitară, București, 2008;

8. Grabowski R. J., King D. -Risk Premium Report, Duff \&Phelps, LLC, 2009;

9. Grama A., Păvăloaia V.D., Comparative Analysis using Bankruptcy Prediction Models. An online computer-based system, European Computer Conference'08, Organizator WSEAS, Malta, Septembrie 2008;

10. Hada T., Halga D., Financial decisions based on diagnosis analysis,Journal of Applied Research in Finance(JARF) 1(5)/2011;

11. Hristea Anca Maria, Analiza economică și financiară a activității întreprinderii, Editura Economică, vol. I, București, 2013, ISBN: 978973-709-646-3

12. Ioniţă I., Stoica M., A new approach method of company valuation, Romanian Journal of Economic Forecasting, 10(1), 2009;

13. Lala -Popa I., Miculeac M.E., Analiza economico-financiară-elemente teoretice și studii de caz, Editura Mirton, Timișoara, 2009;

14. Li J., Rahgozar R., Application of the Z -Score Model with Consideration of Total Assets Volatility in Predicting Corporate Financial Failures from 2000-2010, Journal of Accounting \& Finance, 2012;

15. Mânecuta C., Nicolae M., Construirea şi utilizarea funcției-scor pentru diagnosticarea eficienţei agenţilor economici, Revista Finanţe, Credit, Contabilitate, 5, 1996;

16. Petrescu S., Analiză și diagnostic financiar-contabil, Ghid teoretico-aplicativ, Editura C.E.C.C.A.R., București, 2006;

17. Prisăcariu M., Ursu S., Andrieș A., Piețe și instrumente financiare, Editura Universității A.I. Cuza, Iași, 2008;

18. Revsine L., Collins D., Johnson B., Mittelstaedt F., Financial Reporting and Analysis, 4th Edition, Prentice Hall, 2008;

19. Robu M.A., Mironiuc M., Robu I.B., Un model practic pentru testarea ipotezei de „going concern” în cadrul misiunii de audit financiar pentru firmeleromânești cotate, Revista Audit Financiar, Anul X, nr. 86-2/2012

20. Robu V., Anghel I., Şerban Elena-Claudia, Analiza economico-financiară a firmei, Editura Economică, București, 2014, ISBN: 978-973709-683-8;

21. Stancu I., Stancu D., Delimitări conceptuale şi metodologice ale indicatorilor de cash, cash-flow şi cash-flow disponibil ale întreprinderii, Revista „Audit financiar”, CAFR, anul XII, nr. 118-10/2014;

22. Vâlceanu Gh., Robu V., Georgescu N., Analiza economico-financiară, Editura Economică, București, 2006; 